\title{
THE RESPONSE OF NORMAL INDIVIDUALS AND PATIENTS WITH DIABETES INSIPIDUS TO THE INGESTION OF WATER ${ }^{1}$
}

\author{
By THOMAS FINDLEY, JR., AND H. L. WHITE \\ (From the Departments of Medicine and of Physiology, Washington University Medical School \\ and Barnes Hospital, St. Louis)
}

(Received for publication November 4, 1936)

The physiological adjustments which follow the ingestion of excessive amounts of water and culminate in the familiar water diuresis are by no means understood. Demonstrable changes in the blood attributable to the absorption of water from the intestinal tract are so trifling in comparison with the enormous fluctuations in urine volume as to militate against suggestion that hydremia is per se the immediate stimulus to water release. Indeed, it has been difficult to demonstrate any consistent blood dilution after the absorption of even huge amounts of water, the more so because reduced concentrations of the colloidal non-diffusible constituents of blood do not necessarily imply an increment of circulating water. Haldane and Priestley (16), Adolph (1) and Veil (39) were unable to reduce the concentration of hemoglobin significantly by forcing fluids, and Davis (10), Dresel and Leitner (11), Fee (13), Verney (40) and Smirk $(34,36)$ observed no correlation between this value and the intensity of experimental polyuria; the large reductions reported by Marx $(23,25)$ seem decidedly beyond the usual experience. Macallum and Benson (21) and Siebeck (33) noted no drop in the erythrocyte count following the ingestion of water but Daniel and Högler (9) reported dilutions to 12 per cent. In the experiments of Engel and Scharl (12), Priestley (28) and Rioch (30) the refractive index of serum did not change significantly throughout the course of water diuresis, and Strauss and Chajes (37), Brunn (6) and Daniel and Högler (9) reported only minimal declines; the dilutions of 10 to 20 per cent found in infants by Bakwin (2) and in decerebrate dogs by Bayliss and Fee (3) are unique. Variations in the concentrations of plasma or serum proteins are also so slight as to be of doubtful importance (Brunn (6), Veil (39), Dresel and Leitner (11),

1 Read before the Central Society for Clinical Research, Chicago, Ill., November 6, 1936.
Rioch (30, 31), Fremont-Smith, Putnam and Cobb (14), Smirk $(34,36))$. Jones (18) found but the slightest drop in blood specific gravity after drinking water; Verney (40) no change in plasma colloidal osmotic pressure; Daniel and Högler (9) and Rioch (30) no important change in serum viscosity; Davis (10), Veil (39) and Fremont-Smith et al. (14) very slight reductions in freezing point depression; Margaria (22) a slight increase in the vapor pressure of blood. The blood volume studies of Marx and Mohr (25) and Dresel and Leitner (11) are contradictory and difficult to evaluate. A somewhat greater consistency has been obtained by the gravimetric estimation of total solids : the reports of Blix (4), Rominger (32), Priestley (29), Davis (10), Marx (24), Brahn and Bielschowsky (5), Rioch (31), Fremont-Smith et al. (14) and Smirk $(34,36)$ indicate that a drop of 1 to 2 per cent may be expected to accompany water diuresis. These data seem to show that hydremia, if present, must be extremely slight. The extreme values reported by Greene and Rowntree (15), Underhill and Sallick (38) and Chanutin, Smith and Mendel (8) were obtained from animals intoxicated with water.

In contrast are the relatively consistent reports concerning variations in blood electrolytes. Although Bayliss and Fee (3) found no change in the serum electrical conductivity of decerebrate dogs following water administration in nearly half of their experiments, Wilson (41), Priestley (29) and Rioch $(30,31)$ have described consistent reductions of 3 to 6 per cent, and these are for the most part substantiated by the chloride determinations of Brunn (6), Priestley (29), Marx (23), Dresel and Leitner (11), Fremont-Smith et al. (14) and Smirk (36). The exact figures vary somewhat but with the exception of some of Bayliss and Fee's experiments, the drop in electrical conductivity seems to be uniformly greater than the dilution of the nondiffusible blood constituents 
and markedly in excess of any change attributable to diminished serum viscosity. It appears, therefore, that the plasma hypotonia which follows the ingestion of water is due largely to the rapid outward diffusion of salts into the intestinal contents and body tissues (Burns and Visscher (7)) and only in small part to hydremia.

It has been repeatedly asserted that this reduction in total osmotic pressure is responsible for the ensuing diuresis, but a causal relationship is pure assumption. Priestley (29) maintained that the increased diffusion pressure of blood water directly depresses the capacity of the renal tubule to reabsorb water; but Verney and his associates (19), stressing the similarity between the polyurias of water diuresis, the isolated kidney and diabetes insipidus, have emphasized the importance of the time interval that separates the disappearance of the water from the gut and its reappearance in the urine. By a variety of methods, the important fact has been established that the peak of diuresis does not occur until well after the maximum decrease in the total molecular concentration of plasma has been passed (Marx (24), Rioch (30, 31), Dresel and Leitner (11), Fee (13), Verney (40), Bayliss and Fee (3), Heller and Smirk (17), Verney and associates (19), Smirk $(34,35,36)$, Newton and Smirk (27)). Rioch, for example, found that the maximum dilution of blood electrolytes preceded maximum diuresis by 15 to 20 minutes; Verney that the maximum water load of the body was attained about 15 minutes before the peak of diuresis; Newton and Smirk that the average diuresis did not begin until 40 minutes after the administration of water, that maximum elimination was reached in 126 minutes, and that a 20 minute lag existed between the maximum water load and the peak of diuresis. It is in terms of the latent period that the essential stimulus to water excretion has been sought.

Klisiecki, Pickford, Rothschild and Verney (19) explain the latent period by postulating that the renal absorption of water is dependent upon an adequate concentration in the blood of a pitressin-like substance, the manufacture of which is regulated by "the concentration of water in the blood and tissues, as signified by their aqueous vapour pressures." The delay in diuresis is therefore due to the time required for blood pi- tressin to fall below its threshold level in response to the electrolyte dilution created by water ingestion. The polyurias of the perfused isolated kidney, of the piqûre experiments and of diabetes insipidus are likewise attributed to hypopitressinemia and are, of course, unaccompanied by blood dilution. In order to substantiate this theory it becomes necessary to demonstrate that in these latter conditions the delayed renal excretion of water so characteristic of water diuresis is diminished or absent. Verney himself (19) has published preliminary observations on one case of diabetes insipidus which seem to indicate that this is in fact true, and it was with the object of confirming his findings that the following work was undertaken.

\section{METHODS}

Throughout these relatively acute experiments the subjects have voided at 10 to 20 minute intervals and have drunk frequently in amounts approximating their normal requirements. Except as stated below in regard to some of the observations on diabetes insipidus, it is believed that all subjects were normally hydrated. After a satisfactorily steady flow of urine was established a large volume of water $(1200 \mathrm{cc}$. for the normals, 2000 cc. for the patients) was drunk within 5 minutes, and the urine collections were continued until well into the ebb of diuresis. Blood samples were taken from the basilic vein, usually with no stasis whatever; occasionally momentary pressure was necessary, but control estimations showed that transient mild pressure did not alter the results. Blood was drawn into a dry syringe and the serum separated by centrifugation as soon as clotting was complete. No attempt was made to prevent loss of $\mathrm{CO}_{2}$. Total solids were determined by drying approximately $1 \mathrm{cc}$. samples to constant weight at $105^{\circ} \mathrm{C}$. The average deviation from the mean of 6 control estimations from the same sample of serum was \pm 1.65 per cent. Serum proteins were determined refractometrically. The specific conductivity was determined by the usual bridge method, using a Leeds and Northrup 1000 -cycle generator. The cell was immersed in a thermostatically controlled water bath at $25 \pm$ $0.002^{\circ} \mathrm{C}$. The cell used requires about $0.4 \mathrm{cc}$; its cell constant is 8.16 at $25^{\circ} \mathrm{C}$., where cell constant is defined as observed resistance divided by 
specific resistance. Determinations were reproducible to 0.05 per cent.

\section{RESULTS}

Eight control observations have been made on 3 normal subjects. In all 8 the electrical conductivity of the serum was followed, and in 5, the total blood solids were also determined; in the remaining 3 experiments serum proteins were estimated refractometrically. After the ingestion of a large volume of water the average reduction in specific conductivity for the entire series was 2.7 per cent, the smallest being 1.75 per cent and the greatest 4.9 per cent. The 5 curves illustrating changes in concentration of total solids showed marked inconsistencies. Not much importance is attached to them, as the fluctuations were not often significantly beyond the apparent limit of analytical error. Their general direction, however, is negative and we believe they indicate slight hydremia, since, in 4 , the maximum deflection averaged -3 per cent while 1 showed a maximum increase of nearly 2 per cent. The re- fractometric readings were even more anomalous, varying from +8 per cent to -7 per cent with virtually no average deviation from normal.

Figure 1 shows a typical experiment on each of 3 subjects, 1 with estimations of serum protein and 2 with estimations of total solids. Attention is called to the very definite time interval that separates the point of maximum electrolyte dilution in the blood from the maximum rate of urine formation. In 7 acceptable experiments the apparent intervals were 45, 20, 40, 40, 40, 40 and 35 minutes, an average of 37 minutes.

Attention was then turned to diabetes insipidus with the expectation that, Verney's theory being correct, this time-lag would be much diminished. To our surprise we were unable to produce anything which resembled a flood diuresis, the urine flow remaining relatively constant under varying conditions of fluid intake. Figure 2 (Curve $A$ ) shows a prolonged experiment on such a patient. The blood changes are somewhat more pronounced than in the average normal; but, in spite of the ingestion of $2000 \mathrm{cc}$. of water above the

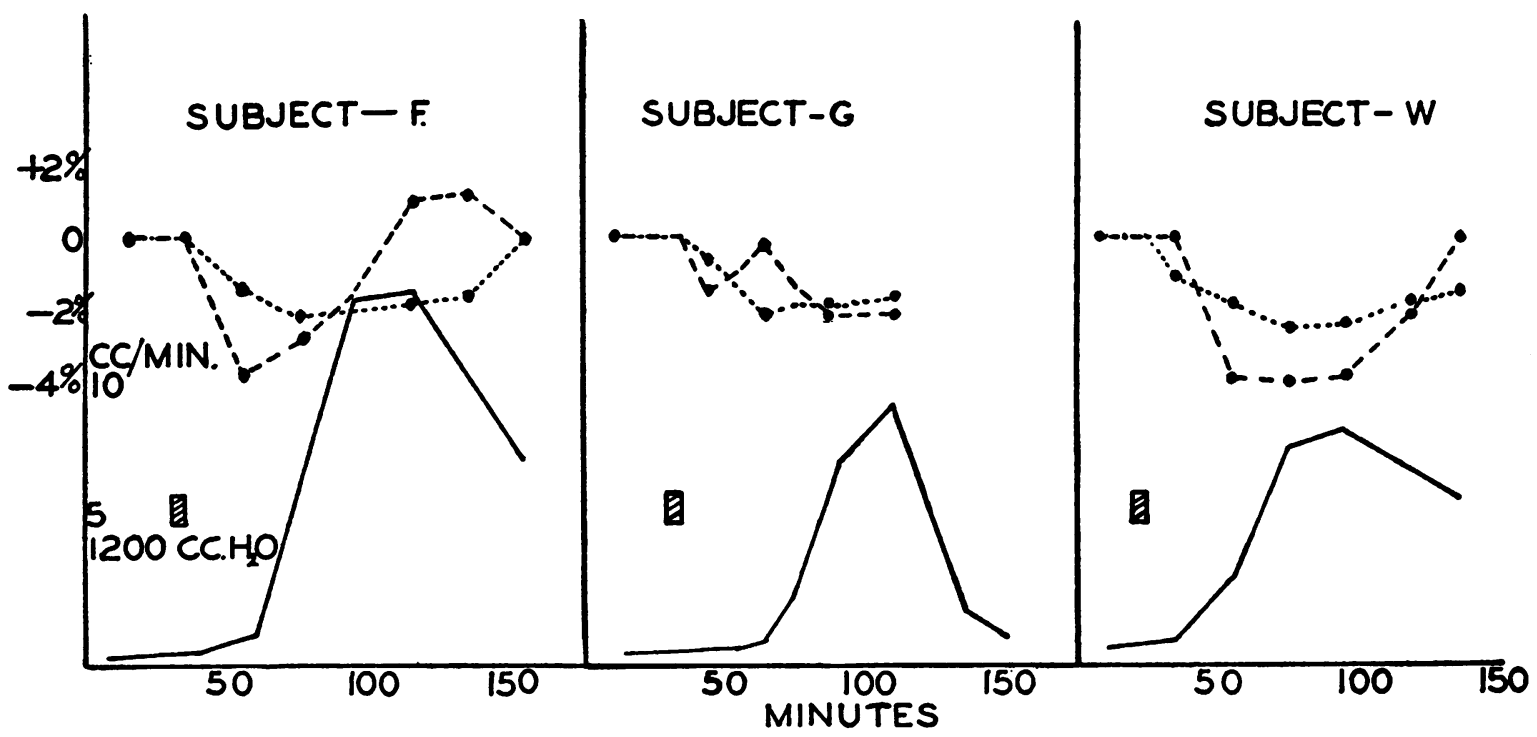

Fig. 1. The Response of Normal Subjects to the Ingestion of Water

$=$ urine flow in cc. per minute.

- $=$ serum total solids in Subjects $F$ and $G$, serum refractive index in Subject W. The serum values are plotted as percentage deviations from the pre-ingestion levels. Initial serum specific conductivity: $F=0.01227 ; G=0.01186 ; W=$ 0.01189. Initial serum total solids: $F=7.64$ grams per cent; $G=8.88$ grams per cent. Initial serum protein: $W=7.87$ grams per cent. The shaded rectangles indicate the ingestion of 1200 cc. tap water.

The uniform drop in the electrical conductivity values is in contrast to the irregular and probably unimportant fluctuations in total solids and protein determinations. The time interval separating the maximum decrease in specific conductivity of the serum from the peak of diuresis is to be noted. 


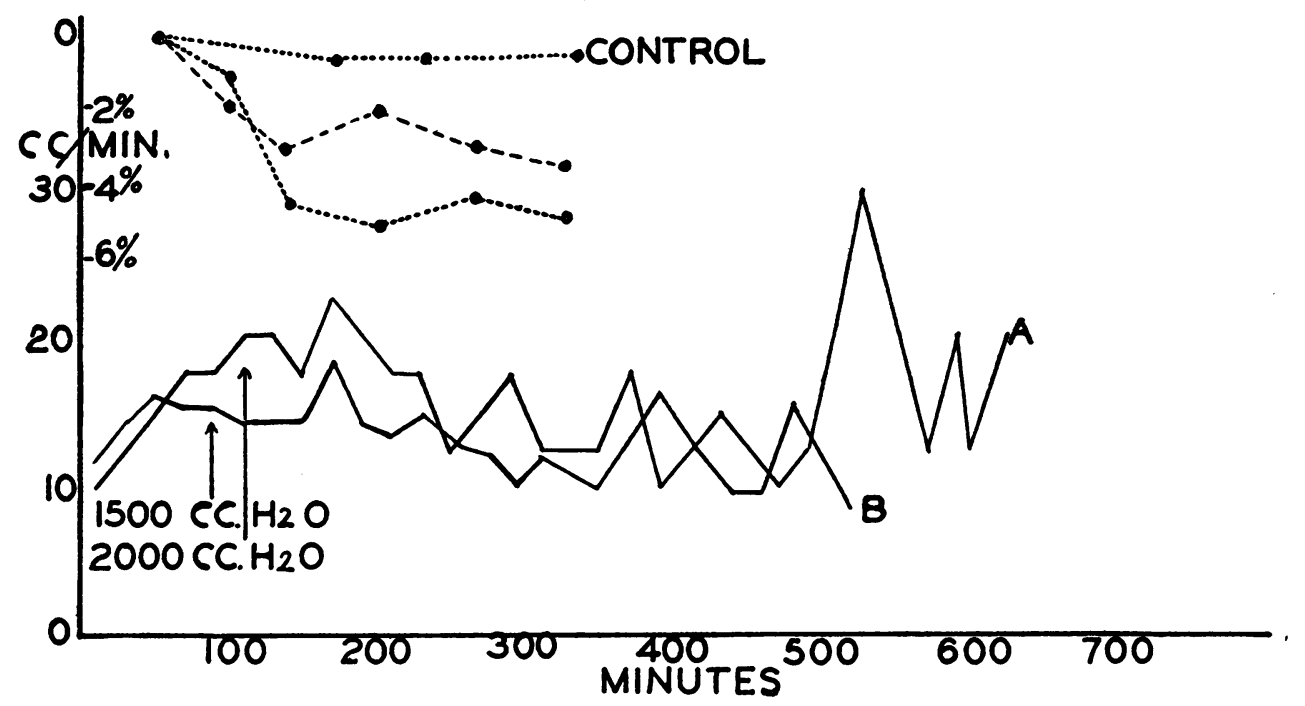

Fig. 2. Water Retention in Diabetes Insipidus. Subject B

\begin{abstract}
- $=$ urine flow in cc. per minute. $\bullet . . . \bullet=$ serum specific conductivity (initial value, 0.01116$) ; 0 .---1=$ serum total solids expressed as percentage deviation from the preingestion value (initial value, 8.13 grams per cent).

Experiment $A$ shows the blood and urine changes accompanying the ingestion of $2000 \mathrm{cc}$. tap water. Throughout the entire observation period the patient drank $400 \mathrm{cc}$. water every 20 minutes. In Experiment $B$ the basal water intake was 200 cc. every 20 minutes; no blood studies were made. Despite the submaximal excretory rate and the large dilution of blood electrolytes no diuresis was initiated in either case. The control electrical resistance determinations were made at random intervals during a normal unrestricted day.
\end{abstract}

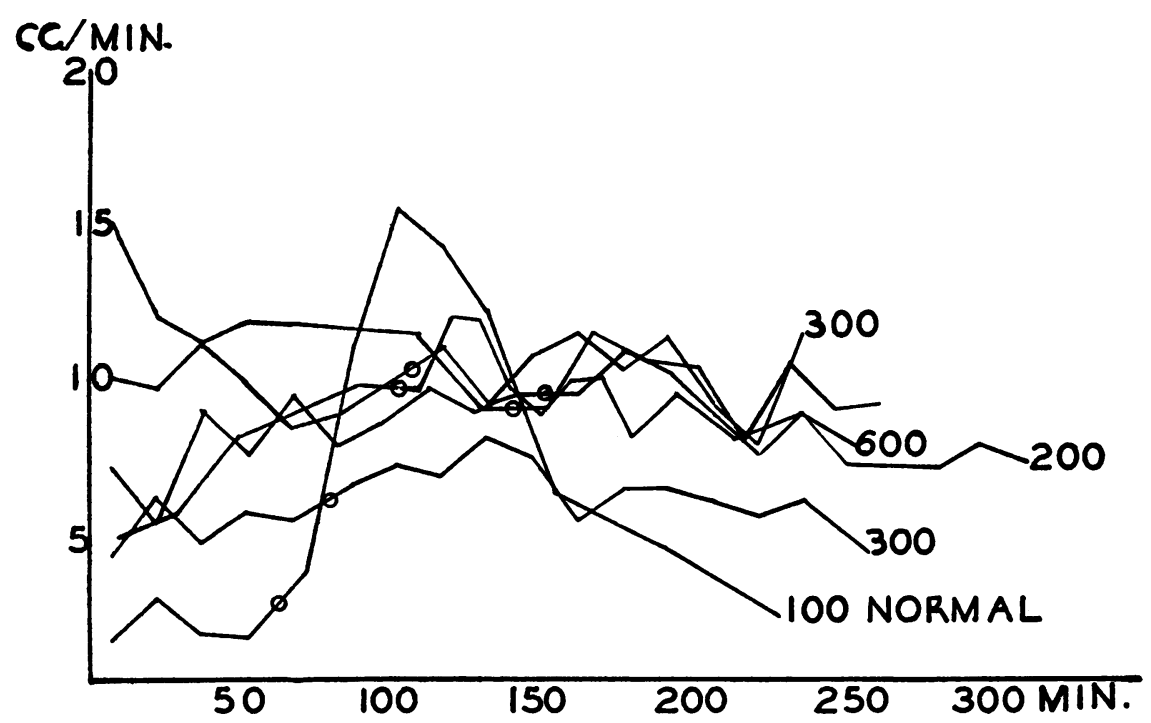

Fig. 3. Water Retention in a Second Case of Diabetes Insipidus. Subject D

Urine flow is recorded in cc. per minute. The circles represent the ingestion of 1200 to $2000 \mathrm{cc}$. tap water, and the figure appended to each curve represents the hourly basal fluid intake maintained throughout the experiment and given at 15 to 20 minute intervals. Despite widely varying basal urine output the patient released extra water very slowly, in comparison with the depicted normal response. 
patient's basal intake, no diuresis occurred within 8 hours. Since the basal fluid intake throughout the experiment was $1200 \mathrm{cc}$. per hour, rather more than he ordinarily consumed, it seemed possible that his kidneys were already responding at a maximal rate and that no increase in urine formation should be expected. However, he had been repeatedly known to excrete more than $20 \mathrm{cc}$. per minute. Despite the fact that this figure represented a submaximal excretory rate it was decided to repeat the observation when the basal urine flow was considerably below the known capacity of the kidneys. Curve $B$ in Figure 2 represents a repetition of this experiment, without blood data, however, done on a basal fluid intake of $600 \mathrm{cc}$. per hour. Figure 3 represents a series of efforts to induce water diuresis in a second patient with diabetes insipidus. By varying the basal fluid intake the urine flow could within certain limits be controlled, although identical intakes on different days resulted in variable urine outputs. It will be seen that despite widely varying basal urine outputs no curve resembling water diuresis was ever obtained.

\section{DISCUSSION}

Water diuresis has been studied in diabetes insipidus with the anticipation that the latent period between the point of maximum blood electrolyte dilution after water ingestion and the peak of diuresis would be less than normal, if Verney's theory is correct. No evidence either for or against this hypothesis has been obtained, however, since it proved impossible to influence the rate of urine flow appreciably by the oral administration of water, although the blood changes were normal in kind and somewhat exaggerated in magnitude. We recognize the dangers incurred in speaking of optimal water requirements in diabetes insipidus and the relative futility of attempting to correlate fluid intake and output in this condition, but call attention to the fact that no sharp and significant rise in urine flow was ever induced even though the patients were not thirsty and were excreting urine at rates below the known capacity of their kidneys to do so. If it be argued that the diabetes insipidus patient is polyuric because he lacks pitressin then some accessory mechanism of water control must be postulated to account for his capacity to retain extra water for a period of at least 8 hours, even in the absence of demonstrable cardiorenal disease. We are therefore unable to confirm Verney's claim that water diuresis is less delayed in diabetes insipidus than in the normal since our patients exhibited no clear-cut renal response to ingested water. On the contrary, it appears that the relative urine volume response of the diabetes insipidus individual to ingested water resembles that of the normal subject to the ingestion of isotonic saline. It is not claimed, of course, that this phenomenon is exhibited by every subject with the disease, for Leschke's patient (20) did excrete an extra 1.5 liters of water in 4 hours. Marx (26), however, has noted that his patients excreted only 20 to 30 per cent of excess water within 4 hours.

\section{CONCLUSIONS}

1. In confirmation of previous work the oral administration of water to normal individuals produces only a slight hydremia, but a definite dilution of blood electrolytes. After an average lag of about 35 minutes diuresis reaches its height.

2. Oral administration of water to individuals with diabetes insipidus, under conditions which should permit an increase in urine output, results in similar blood changes, but in a small and greatly prolonged renal response.

\section{BIBLIOGRAPHY}

1. Adolph, E. F., The regulation of the water content of - the human organism. J. Physiol., 1921, 55, 114.

2. Bakwin, $H$., The significance of hydremia in the secretion of urine. Am. J. Physiol., 1922, 60, 343.

3. Bayliss, L. E. and Fee, A. R., Studies in water diuresis. IV. The changes in the concentration of electrolytes and colloids in the plasma of decerebrate dogs produced by the ingestion of water. J. Physiol., 1930, 70, 60.

4. Blix, G., Über den Wassergehalt des Blutes. Biochem. Ztschr., 1916, 74, 302.

5. Brahn, B. and Bielschowsky, F., Uber Änderung des Wassergehaltes des Blutes nach Peroralen Wassergaben. Klin. Wchnschr., 1928, 7, 2004.

6. Brunn, $F$., Über diuresehemmende und diuretische Wirkung des Pituitrins. Zentralbl. f. inn. Med., 1920, 41, 674.

7. Burns, H. S. and Visscher, M. B., The influence of various anions of the lyotropic series upon the sodium and chloride content of fluid in the intestine. Am. J. Physiol., 1934, 110, 490. 
8. Chanutin, A., Smith, A. H. and Mendel, L. B., Factors concerned in blood volume regulation. Am. J. Physiol., 1924, 68, 444.

9. Daniel, I. and Högler, F., Studien über die Wasserprobe. Wien. Arch. f. inn. Med., 1922, 4, 167.

10. Davis, D. M., The effect of calcium, water and other substances given intravenously on blood composition and urine secretion. J. Urol., 1917, 1, 113.

11. Dresel, $K$. and Leitner, Z., Zur Physiologie des Wasserhaushalts. Veränderungen der Blutmenge und der Blutzusammensetzung nach Flüssigkeitsaufnahme und ihre Beziehungen zur Milzfunktion und zur Diurese. Klin. Wchnschr., 1928, 7, 1362.

12. Engel, K. and Scharl, P., Die Konzentrationsveränderung des Blutserums nach Wasseraufnahme. Ztschr. f. klin. Med., 1906, 60, 225.

13. Fee, A. R., Studies on water diuresis. II. The excretion of urine after hypophysectomy and decerebration. J. Physiol., 1929, 68, 305.

14. Fremont-Smith, F., Putnam, T. J. and Cobb, S., Forced drainage of the central nervous system. Its effect on the blood and on the cerebrospinal fluid. Arch. Neurol. and Psychiat., 1930, 23, 219.

15. Greene, C. H. and Rowntree, L. G., The effect of the experimental administration of excessive amounts of water. I. On the volume and concentration of the blood. Am. J. Physiol., 1927, 80, 209.

16. Haldane, J. S. and Priestley, J. G., The regulation of excretion of water by the kidneys. I. J. Physiol., 1915, 50, 296.

17. Heller, H. and Smirk, F. H., Studies concerning the alimentary absorption of water and tissue hydration in relation to diuresis. J. Physiol., 1932, 76, 4.

18. Jones, E. L., On the variations in the specific gravity of the blood in health. J. Physiol., 1887, 8, 1.

19. Klisiecki, A., Pickford, M., Rothschild, P. and Verney, E. B., The absorption and excretion of water by the mammal. II. Factors influencing the response of the kidney to water-ingestion. Proc. Roy. Soc., London, s.B., 1932, 112, 521.

20. Leschke, E., Beiträge zur klinischen Pathologie des Zwischenhirns. I. Klinische und experimentalle Untersuchungen über Diabetes insipidus, seine Beziehungen zur Hypophyse und zum Zwischenhirn. Ztschr. f. klin. Med., 1919, 87, 201.

21. Macallum, A. B. and Benson, C. C., On the composition of dilute renal excretions. J. Biol. Chem., $1909,6,87$.

22. Margaria, R., The vapour pressure of normal human blood. J. Physiol., 1930, 70, 417.

23. Marx, H., Untersuchungen über den Wasserhaushalt. I. Die Blutverdünnung nach Flüssigkeitaufnahme. Klin. Wchnschr., 1925, 4, 2339.

24. Marx, H., Untersuchungen über den Wasserhaushalt.
III. Uber die Austauschvorgänge zwischen Blut und Gewebe bei Gesunden und Kranken. Deutsches Arch. f. klin. Med., 1926, 152, 354.

25. Marx, H. and Mohr, W., Tierexperimentelle Studien zum Wasserhaushalt. I. Uther Schwankungen der Plasmamenge nach Wasserzufuhr. Arch. f. exper. Path. u. Pharmakol., 1927, 123, 205.

26. Marx, H., Der Wasserhaushalt des gesunden und kranken Menschen. Julius Springer, Berlin, 1935, p. 270.

27. Newton, W. H. and Smirk, F. H., The pituitary gland in relation to polyuria and to water diuresis. $J$. Physiol., 1934, 81, 172.

28. Priestley, J. G., The regulation of excretion of water by the kidneys. II. J. Physiol., 1915, 50, 304.

29. Priestley, J. G., The regulation of the excretion of water by the kidneys. J. Physiol., 1921, 55, 305.

30. Rioch, D. McK., Experiments on water and salt diuresis. Arch. Int. Med., 1927, 40, 743.

31. Rioch, D. McK., Water diuresis. J. Physiol., 1930, $70,45$.

32. Rominger, E., Uber den Wassergehalt des Blutes des gesunden und ernährungsgestörten Säuglings. Ztschr. f. Kinderh., 1920, 26, 23.

33. Siebeck, R., Die Wasserausscheidung durch die Nieren und der Wasserhaushalt des Organismus. Deutsches Arch. f. klin. Med., 1918, 128, 173.

34. Smirk, F. H., Changes in the blood composition of unanaesthetized rabbits following the ingestion of water and saline with special reference to the distribution of fluid between plasma and corpuscles and to the relationship between blood composition and diuresis. J. Physiol., 1932, 75, 81.

35. Smirk, F. H., The rate of water absorption in man and the relationship of the water load in tissues to diuresis. J. Physiol., 1933, 78, 113.

36. Smirk, F. H., The effect of water drinking on the blood composition of human subjects in relation to diuresis. J. Physiol., 1933, 78, 127.

37. Strauss, H. and Chajes, B., Refractometrische Eiweissbestimmungen an menschlichem Blutserum und ihre klinische Bedeutung. Ztschr. f. klin. Med., 1904, $52,536$.

38. Underhill, F. P. and Sallick, M. A., On the mechanism of water intoxication. J. Biol. Chem., 1925, $63,61$.

39. Veil, W. H., Physiologie und Pathologie des Wasserhaushaltes. Ergebn. d. inn. Med. u. Kinderh., 1923, 23, 648.

40. Verney, E. B., Polyuria associated with pituitary dysfunction. Lancet, 1929, 1, 539.

41. Wilson, T. M., Measurement of electrical conductivity for clinical purposes. Am. J. Physiol., 1905, 13, 139. 